\title{
Photoperiodic conditions as a factor modulating leptin influence on pro-inflammatory cytokines and their receptors gene expression in ewe's aorta
}

\author{
A. Krawczyńska ${ }^{1,3}$, H. Antushevich¹, J. Bochenek¹, K. Wojtulewicz'1, B. Pawlina', \\ A.P. Herman ${ }^{1}$ and D.A. Zięba ${ }^{2}$ \\ ${ }^{1}$ The Kielanowski Institute of Animal Physiology and Nutrition, Polish Academy of Sciences, Department of Genetic Engineering, \\ Instytucka 3, 05-110 Jabłonna \\ ${ }^{2}$ Agricultural University of Krakow, Department of Animal Biotechnology, Laboratory of Biotechnology and Genomics, \\ 30-248 Kraków, Poland
}

KEY WORDS: aorta, cytokines, ewes, leptin, lipopolysaccharide, photoperiod

Received: 4 March 2019

Revised: 22 May 2019

Accepted: 17 June 2019

${ }^{3}$ Corresponding author:

e-mail: a.krawczynska@ifzz.pl

\begin{abstract}
Atherosclerosis, a chronic inflammation state of the aorta, is characterised by increased levels of pro-inflammatory cytokines (tumour necrosis factor alpha (TNFa), interleukin (IL)-1 $\beta, I L-6)$. Sheep is used in both cardiovascular and immunological studies; besides, 'long-day' ewe can be a model of leptin resistance state. The aim of the study was to examine whether photoperiodic conditions (long-day (LD) and short-day (SD) seasons) are a key factor modulating exogenous leptin influence on pro-inflammatory cytokines and their receptors gene expression in aorta of ewe's with or without prior induction of acute inflammation. The experiment was conducted on 48 ewes during SD and LD seasons which were randomly divided into 4 groups: control; with LPS injection (400 ng/kg of body weight (BW)); with leptin injection $(20 \mu \mathrm{g} / \mathrm{kg} \mathrm{BW})$; and with LPS and 30-min later leptin injection. Three hours after LPS/control treatment animals were euthanized to collect the thoracic aorta samples. In both seasons leptin injection intensified LPS-induced increase in IL1B gene expression but only in SD season leptin injection increased IL1R1 and IL1R2 gene expressions. The leptin injection increased IL6 gene expression but only in SD season. In the LD season leptin enhanced the LPS effect on IL6 gene expression. Neither TNFA nor its receptors gene expression was influenced by leptin regardless of season. In the thoracic aorta tissue an exogenous leptin exerts effect on pro-inflammatory cytokines and their receptors gene expression; however in ewe this influence depends on photoperiodic conditions. Moreover, leptin can moderate progression of the inflammation reaction in this tissue.
\end{abstract}

\section{Introduction}

Cardiovascular diseases (CVD) such as hypertension, ischemic heart or heart failure, are currently the leading cause of death worldwide. According to World Health Organization (WHO) statistics, in 2008 the number of deaths due to
CVD was $17.3 \mathrm{mln}$, which accounted for nearly $30 \%$ of all deaths (WHO, 2011). The underlying cause of CVD is atherosclerosis which is a chronic inflammation state of the aorta and arteries of medium size (epicardial, coronary, carotid, renal, pelvic, mesenteric). Atherosclerosis can be however treated as 'inflammation disease' in two aspects. 
Firstly, it is a located inflammation state manifested by formation of the fatty streaks transforming into atherosclerotic plaque in the vessels. Secondly, atherosclerosis is accompanied by sub-acute systemic inflammation indicated by increased level of: proinflammatory cytokines (tumour necrosis factor alpha (TNF $\alpha$ ), interleukin (IL)-1 $\beta$, IL-6), adhesive molecules (vascular and intercellular cell adhesion molecules (VCAM, ICAM, respectively)) and acute phase proteins (C-reactive protein, amyloid A, fibrinogen) (Beręsewicz, 2011). It is stated that mechanism of inflammation participating in pathogenesis of atherosclerosis is similar to the pathway of inflammation caused by infection (innate immunity). The main difference constitutes an inductor of the process, which is pathogen or its toxin (such as lipopolysaccharide (LPS)) in the innate immunity (Kumar et al., 2011) and oxidized low density lipoproteins (ox-LDL) (Howell et al., 2011) in atherosclerosis. Both LPS and LDL derivatives activate the path dependent on Toll-like receptor 4 (TLR4). Ligand binding to this receptor activates MyD88dependent or -independent pathways of kinases such as Inhibitor of Nuclear Factor $\kappa B$ Kinase $(\alpha, \beta, \gamma)$ (IKK) or c-Jun N-terminal Kinase (JNK) causing synthesis of pro-inflammatory cytokines (Frantz et al., 2007). The similarities in activating TLR4 by ox-LDL and LPS caused that LPS is used as a model factor for atherosclerosis induction in animals (Yin et al., 2013).

One of the possible large animal model in atherosclerosis research is sheep. So far, it has been used as a model in research on several heart diseases such as ligation-induced myocardial infraction in foetal sheep, embolization-induced myocardial infraction or sudden cardiac death (Camacho et al., 2016). Milani-Nejad et al. (2014) presented several advantages of using sheep as a pre-clinical model for studying cardiovascular diseases. Among them are: close similarities in the cellular level (myosin), heart rate (sheep vs human: 60-120 bpm vs in average $72 \mathrm{bpm}$ ), systolic (sheep vs human: 91-116 vs in average $120 \mathrm{~mm} \mathrm{Hg}$ ) and diastolic (sheep vs human: $102 v s$ in average $80 \mathrm{~mm} \mathrm{Hg}$ ) pressure, contractile and relaxation kinetics and force-frequently relationship. This model provides a valuable alternative to canine or swine models, as it is relatively easy-touse, slow growing (in comparison to swine), cheap (in comparison to minipigs) and leads to less ethical concerns (in comparison to dogs) (Duchenne et al., 2018). It is worth mentioning that sheep is also considered to be an accepted animal model in immunological studies because it shows similar sensitivity to endotoxins as primates in contrast to rodents
(Azevedo, 2012). Moreover, the fact that sheep, in contrast to mouse and rat, is a diurnal animal also influences the immune response because immune system activity exhibits important oscillation over the course of a day (Scheiermann et al., 2013). Besides, during the long-day season (spring/summer) in ewe the phenomenon of natural leptin resistance is observed, which is connected with seasonal adaptation to changes in energy supply and demand. So a 'long-day sheep' can be treated as a model to study hyperleptinemic state (Chilliard et al., 2005). Zięba et al. (2008) made even a further suggestion proposing 'long-day ewe' as a model for obesity research because obese people as 'long-day ewes' are characterized by enhanced food intake and reduced energy expenditure accompanied by high leptin level. The existence of leptin resistance or the changes in leptin sensitivity in the cardiovascular tissues of ewe in different photoperiodic conditions have not been examined yet.

It has to be stressed that leptin, the adipokine structurally similar to cytokines, also plays a key role in vessel functioning. On the one hand, it is essential to maintain the proper functioning of the blood vessels acting as vasodilator (Sikka et al., 2010). On the other hand, leptin also appears to play an important role in the promotion of atherosclerotic lesions, because, as it was stated by Schroeter et al. (2007), leptin receptors are present in the atherosclerotic plaque. The leptin content in the aortic layer depends on environmental factors such as nutrition (Krawczyńska et al., 2013; 2014). Moreover ob/ob mice (with leptin gene knockout) are resistant to atherosclerosis (Yen et al., 1977). One of the leptin mechanism of action is its possible influence on synthesis of pro-inflammatory cytokines in macrophages and monocytes (IL-6, IL-12, IL-18 and TNF $\alpha$ ) (Beltowski, 2006).

Taking into consideration the above mentioned facts, it was hypothesised that photoperiodic conditions (long-day (LD) and short-day (SD) seasons) are a key factor modulating exogenous leptin influence on pro-inflammatory cytokines and their receptors gene expression in aorta of ewe's with or without prior acute inflammation induction.

\section{Material and methods}

\section{Animals and experimental design}

The animal welfare and caring procedures were approved by the $3^{\text {rd }}$ Local Ethical Commission of Warsaw University of Life Sciences - SGGW 
(Warsaw, Poland, authorisation no. 56/2013). During the whole experimental period ewes were in good condition and were kept under constant veterinary care.

The experiment was conducted on 48 adult ( 2-year old) female blackface sheep in natural light conditions (latitude $52^{\circ} \mathrm{N}, 21^{\circ} \mathrm{E}$ ) of SD period (December, day:night 8:16 h) and LD period (June, day:night 16:8 h). The animals were maintained indoors in individual pens and the stress of social isolation was limited by visual contact with other members of the flock. The animals were fed a consistent diet of commercial concentrates with hay and water available ad libitum according to the recommendations of National Research Institute of Animal Production (Krakow, Poland) (Strzetelski et al., 2014).

In the SD period experiment the stage of the oestrous cycle of ewes was synchronized by the Chronogest $^{\circledR}$ CR method (Merck Animal Health, Boxmeer, The Netherlands). The experimental procedure began $24 \mathrm{~h}$ following pregnant mare's serum gonadotropin (PMSG) injection, so the ewes were in the follicular phase of the oestrous cycle. During the LD period the animals were in seasonal anoestrous so synchronization was not required.

In both seasons the animals were randomly divided into 4 groups, $\mathrm{n}=6$ in each: 1 . control (C), 2. with LPS injection to induce immune stress (LPS), 3. with leptin injection (LEP) and 4. with LPS and leptin injection (LPS+LEP). The LPS from Escherichia coli 055:B5 (Sigma-Aldrich, St. Louis, MO, USA) was dissolved in saline $(0.9 \% \mathrm{w} / \mathrm{v} \mathrm{NaCl})$ (Baxter, Deerfield, IL, USA) and injected into jugular vein at a dose of $400 \mathrm{ng} / \mathrm{kg}$ of body mass (Herman and Tomaszewska-Zaremba, 2010). The recombinant sheep leptin (Protein Laboratories Rehovot (PLR) Ltd., Rehovot, Israel) at a dose of $20 \mu \mathrm{g} / \mathrm{kg}$ of body mass (based on doses used for growing beef heifers according to Maciel et al. (2004)) also dissolved in saline was injected $30 \mathrm{~min}$ after LPS treatment. The control animals received an equivalent volume of saline at the moment of LPS and/or leptin injection.

During the experimental day animals were euthanized $3 \mathrm{~h}$ after LPS/saline treatment ( $2.5 \mathrm{~h}$ after exogenous leptin/saline injection) and the aorta fragments located about $2 \mathrm{~cm}$ from the heart were collected. All tissues were frozen in the liquid nitrogen and stored at $-80{ }^{\circ} \mathrm{C}$.

\section{Relative mRNA expression}

Total RNA from the aorta samples was isolated using the NucleoSpin ${ }^{\circledR}$ RNA kit (Macherey-Nagel GmbH \& Co, Düren, Germany) according to the manufacturer's instruction with additional proteinase $\mathrm{K}$ treatment (Macherey-Nagel GmbH \& Co, Düren, Germany). The quantity and quality of isolated total RNA were quantified spectrophotometrically at 260 and $280 \mathrm{~nm}$ with the use of NanoDrop 1000 instrument (ThermoFisher Scientific Inc., Waltham, MA, USA). The RNA integrity was checked by $1 \%$ agarose gel electrophoresis. The cDNA synthesis was performed using the Maxima ${ }^{\mathrm{TM}}$ First Strand cDNA Synthesis Kit for RT-qPCR (ThermoFisher Scientific Inc., Waltham, MA, USA) according to the manufacturer's instruction. $1200 \mathrm{ng}$ of total RNA was used as starting material for reversed transcription in reaction volume of $20 \mathrm{ml}$.

Real-time PCR assay was carried out with use of 5x HOT FIREPol EvaGreen qPCR Mix Plus (no ROX) (Solis BioDyne, Tartu, Estonia) and HPLC-grade oligonucleotide primers purchased from Genomed (Warsaw, Poland). Specific primers for determining the expression of examined and reference genes are presented in Table 1. Each PCR reaction contained: $3 \mu \mathrm{l}$ qPCR Mix, $10 \mu 1$ RNase-free water, $0.225 \mu \mathrm{l}$ of each primer (working concentration $0.5 \mathrm{mM}$ ) and $1.5 \mu \mathrm{l} \mathrm{cDNA}$ template (previously $3 \times$ diluted). The reactions were run on the RotorGene Q thermocycler (Qiagen, Dusseldorf, Germany) using the following protocol: $95{ }^{\circ} \mathrm{C}$ for $15 \mathrm{~min}$ and 35 cycles of $94^{\circ} \mathrm{C}$ for $5 \mathrm{~s}$ for denaturation, $59^{\circ} \mathrm{C}$ for $20 \mathrm{~s}$ for annealing and $72{ }^{\circ} \mathrm{C}$ for $5 \mathrm{~s}$ for extension. After the cycles, a final melting curve analysis with continuous fluorescence measurements was performed to confirm the specificity of the amplification.

The relative gene expression was calculated using the comparative quantification option of the Rotor Gene Q Series Software 2.0.3 (Qiagen, Dusseldorf, Germany). To compensate for variation in cDNA concentrations and PCR efficiency between samples, an endogenous control gene was amplified in each sample and used for normalization. Initially, three reference genes (HDACl, ACTB and GAPDH) were tested; however after analysis with the use of NormFinder software ver. 20 (Molecular Diagnostic Laboratory, Aarhus University Hospital, Aarhus, Denmark) the $H D A C l$ gene was stated as the endogenous control with the best expression stability in the experimental design. The results are presented in arbitrary units, as the ratio of the target gene expression to the expression of the reference gene with control group was calculated as 1 .

\section{Statistical analysis}

Statistical analysis was performed using Statistica ver. 13.1 (Dell Inc., Round Rock, TX, USA). 
Table 1. Analysed genes with Gene Bank accession number, amplicon size, location in gene sequence and primers characteristics

\begin{tabular}{|c|c|c|c|}
\hline $\begin{array}{l}\text { Gene Bank Acc. } \\
\text { No. }\end{array}$ & Gene & $\begin{array}{l}\text { Amplicon size, bp } \\
\text { (localization in the } \\
\text { gene sequence) }\end{array}$ & $\begin{array}{l}\text { Primer (Forward, F; Reverse, R) Reference } \\
\text { sequence } 5 \text { ' } \rightarrow \text { ' }\end{array}$ \\
\hline NM_001009465.2 & $\begin{array}{l}\text { IL1B } \\
\text { interleukin-1 } \beta\end{array}$ & $137(373-509)$ & $\begin{array}{l}\text { F: CAGCCGTGCAGTCAGTAAAA Herman et al., } 2010 \\
\text { R: GAAGCTCATGCAGAACACCA }\end{array}$ \\
\hline NM_001206735.1 & $\begin{array}{l}\text { IL1R1 } \\
\text { IL1 receptor, type I }\end{array}$ & $124(1455-1578)$ & $\begin{array}{l}\text { F: GGGAAGGGTCCACCTGTAAC Herman et al., } 2014 \\
\text { R: ACAATGCTTTCCCCAACGTA }\end{array}$ \\
\hline NM_001046210.2 & $\begin{array}{l}\text { IL1R2 } \\
\text { IL1 receptor, type II }\end{array}$ & $161(981-1141)$ & $\begin{array}{l}\text { F: CGCCAGGCATACTCAGAAA originally designed }{ }^{1} \\
\text { R: GAGAACGTGGCAGCTTCTTT }\end{array}$ \\
\hline NM_001009392.1 & $\begin{array}{l}\text { IL6 } \\
\text { interleukin } 6\end{array}$ & $165(361-525)$ & $\begin{array}{l}\text { F: GTTCAATCAGGCGATTTGCT Herman et al., } 2014 \\
\text { R: CCTGCGATCTTTTCCTTCAG }\end{array}$ \\
\hline NM_001110785.3 & $\begin{array}{l}\text { IL6R } \\
\text { IL6 receptor }\end{array}$ & $149(288-436)$ & $\begin{array}{l}\text { F: TCAGCGACTCCGGAAACTAT Herman et al., } 2014 \\
\text { R: CCGAGGACTCCACTCACAAT }\end{array}$ \\
\hline XM_012096909.2 & $\begin{array}{l}\text { IL6ST } \\
\text { IL6 signal transducer (glycoprotein 130) }\end{array}$ & 139 (573-711) & $\begin{array}{l}\text { F: GGCTTGCCTCCTGAAAAACC Król et al., } 2016 \\
\text { R: ACTTCTCTGTTGCCCACTCAG }\end{array}$ \\
\hline NM_001024860.1 & $\begin{array}{l}\text { TNFA } \\
\text { tumour necrosis factor }\end{array}$ & $153(426-578)$ & $\begin{array}{l}\text { F: CAAATAACAAGCCGGTAGCC Herman et al., } 2014 \\
\text { R: AGATGAGGTAAAGCCCGTCA }\end{array}$ \\
\hline NM_001166185.1 & $\begin{array}{l}\text { TNFAR1 (TNFRSF1A) } \\
\text { TNF receptor, type I (TNF superfamily member } 1 \mathrm{~A} \text { ) }\end{array}$ & 137 (310-446) & $\begin{array}{l}\text { F: AGGTGCCGGGATGAAATGTT Herman et al., } 2014 \\
\text { R: CAGAGGCTGCAGTTCAGACA }\end{array}$ \\
\hline NM_001040490.2 & $\begin{array}{l}\text { TNFAR2 (TNFRSF1B) } \\
\text { TNF receptor, type II (TNF superfamily member 1B) }\end{array}$ & $122(772-893)$ & $\begin{array}{l}\text { F: ACCTTCTTCCTCCTCCCAAA Herman et al., } 2014 \\
\text { R: AGAAGCAGACCCAATGCTGT }\end{array}$ \\
\hline NM_001135930.1 & $\begin{array}{l}\text { TLR4 } \\
\text { toll like receptor } 4\end{array}$ & $112(248-359)$ & $\begin{array}{l}\text { F: TGGATTTATCCAGATGCGAAA originally designed }{ }^{1} \\
\text { R: CCCCAGGCTAAACTCTGGAT }\end{array}$ \\
\hline NM_001190390.1 & $\begin{array}{l}\text { GAPDH } \\
\text { glyceraldehyde-3-phosphate dehydrogenase }\end{array}$ & $143(135-258)$ & $\begin{array}{l}\text { F: TGACCCCTTCATTGACCTTC Herman et al., } 2010 \\
\text { R: GATCTCGCTCCTGGAAGATG }\end{array}$ \\
\hline NM_001009784.2 & $\begin{array}{l}\text { ACTB } \\
\text { beta actin }\end{array}$ & $122(426-547)$ & $\begin{array}{l}\text { F: GCCAACCGTGAGAAGATGAC originally designed }{ }^{1} \\
\text { R: TCCATCACGATGCCAGTG }\end{array}$ \\
\hline XM_004005023.3 & $\begin{array}{l}\text { HDAC1 } \\
\text { Histone deacetylase } 1\end{array}$ & 115 (722-836) & $\begin{array}{l}\text { F: CTGGGGACCTACGGGATATT Herman et al., } 2014 \\
\text { R: GACATGACCGGCTTGAAAAT }\end{array}$ \\
\hline
\end{tabular}

${ }^{1}$ primers were designed using Primer3web version 4.0.0 (http://bioinfo.ut.ee/primer3/)

The results obtained for each photoperiod were analysed separately. Results of two-way (LPS and leptin injection) analysis of variance (ANOVA) followed by Tukey's post-hoc test were considered statistically significant at $P \leq 0.05$. The ANOVA test was performed after its two assumptions: normality (Shapiro-Wilk's test) and homogeneity of variances (Levene's test) were checked. The post-hoc test was performed only if one of the main factors exerted significant effect according to ANOVA test. All data are showed as means \pm standard deviation (SD).

\section{Results}

\section{Toll-like receptor 4 (Figure 1)}

Regardless the day length conditions, endotoxin injection increased TLR4 gene expression (ANOVA, $P \leq 0.001$ for $\mathrm{SD}$ and $\mathrm{LD}$ seasons). In the SD season the effect of leptin was also stated (ANOVA, $P \leq 0.04$ ); but the group with leptin injection differ neither from control nor from LPS-treated groups. In the LD season no effect of leptin on TLR4 gene expression was observed.

\section{Interleukin-1 $\beta$ and its receptors (Figure 2)}

The obtained results showed that, regardless the season, the LPS injection increased gene expression of ILIB and its both receptors (ILIRI and $I L 1 R 2$ ) (ANOVA, $P \leq 0.0001$ for all three genes in both seasons). The exogenous leptin injection also influenced $I L 1 B$ gene expression regardless examined season (ANOVA $P \leq 0.005$ for both seasons); however there was no difference between $\mathrm{C}$ and leptin-treated group (Tukey's test, C vs LEP, $P \geq 0.05$ ) but in both seasons leptin injection intensified LPS-induced increase in $I L 1 B$ gene expression (Tukey's test, LPS vs LPS+LEP, $P \leq 0.0003$ and $P \leq 0.003$ for $\mathrm{SD}$ and LD season, respectively). Leptin injection increased ILIRI and $I L 1 R 2$ gene expression but only in SD season (Tukey's test, $\mathrm{C} v s$ LEP, $P \leq 0.03$ and $P \leq 0.04$ for ILIRI and ILIR2, respectively), however no cumulative effect of LPS and leptin was stated on these genes expression.

\section{Interleukin-6 and its receptors (Figure 3)}

The endotoxin injection exerted effect on IL6, its receptor (IL6R) and its signal transducer (IL6ST) 

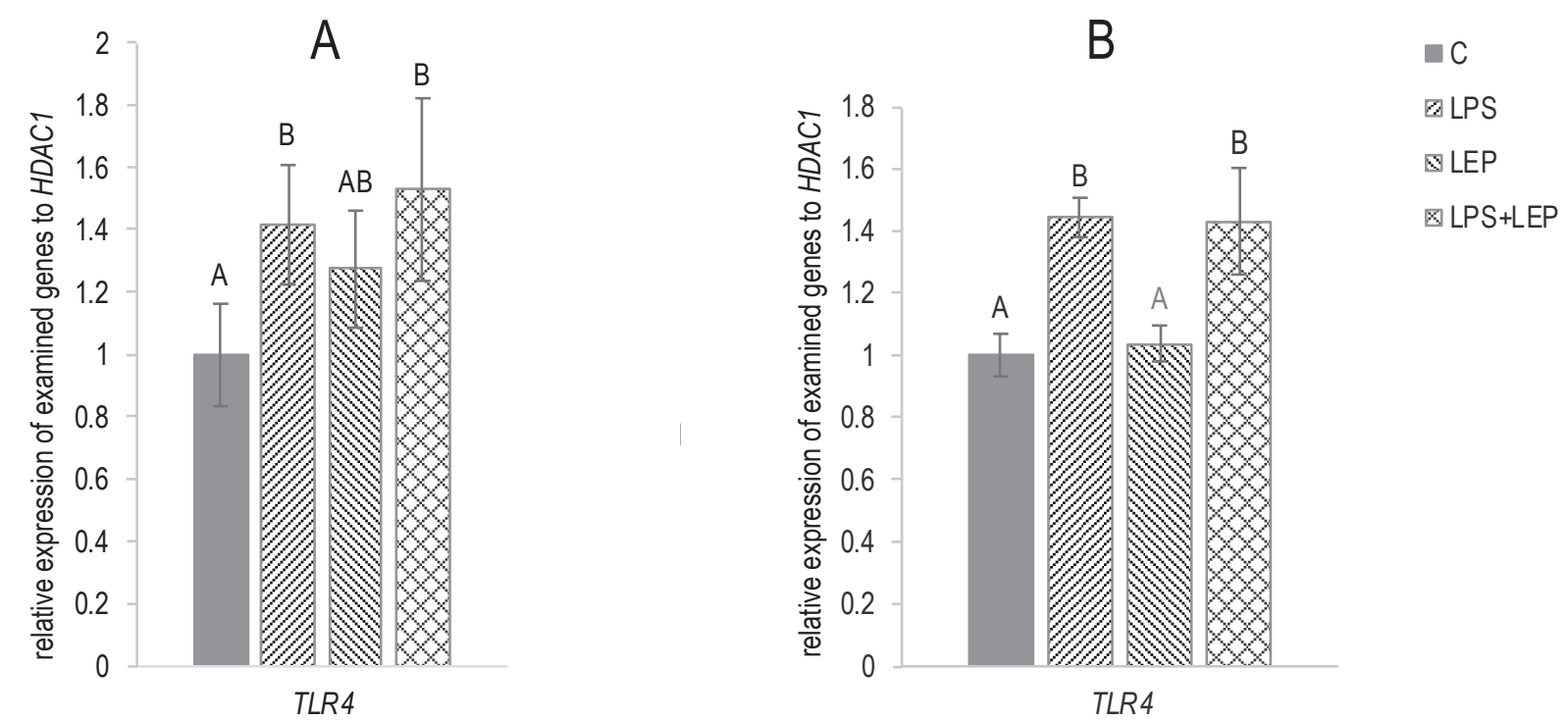

Figure 1. Relative gene expression of Toll-like receptor 4 (TLR4) in ewe's aorta during short-day (A) and long-day (B) seasons $A B C$ - bars with different superscripts are significantly different according to two-way ANOVA with post-hoc Tukey's test, for each gene separately, at $P \leq 0.05$
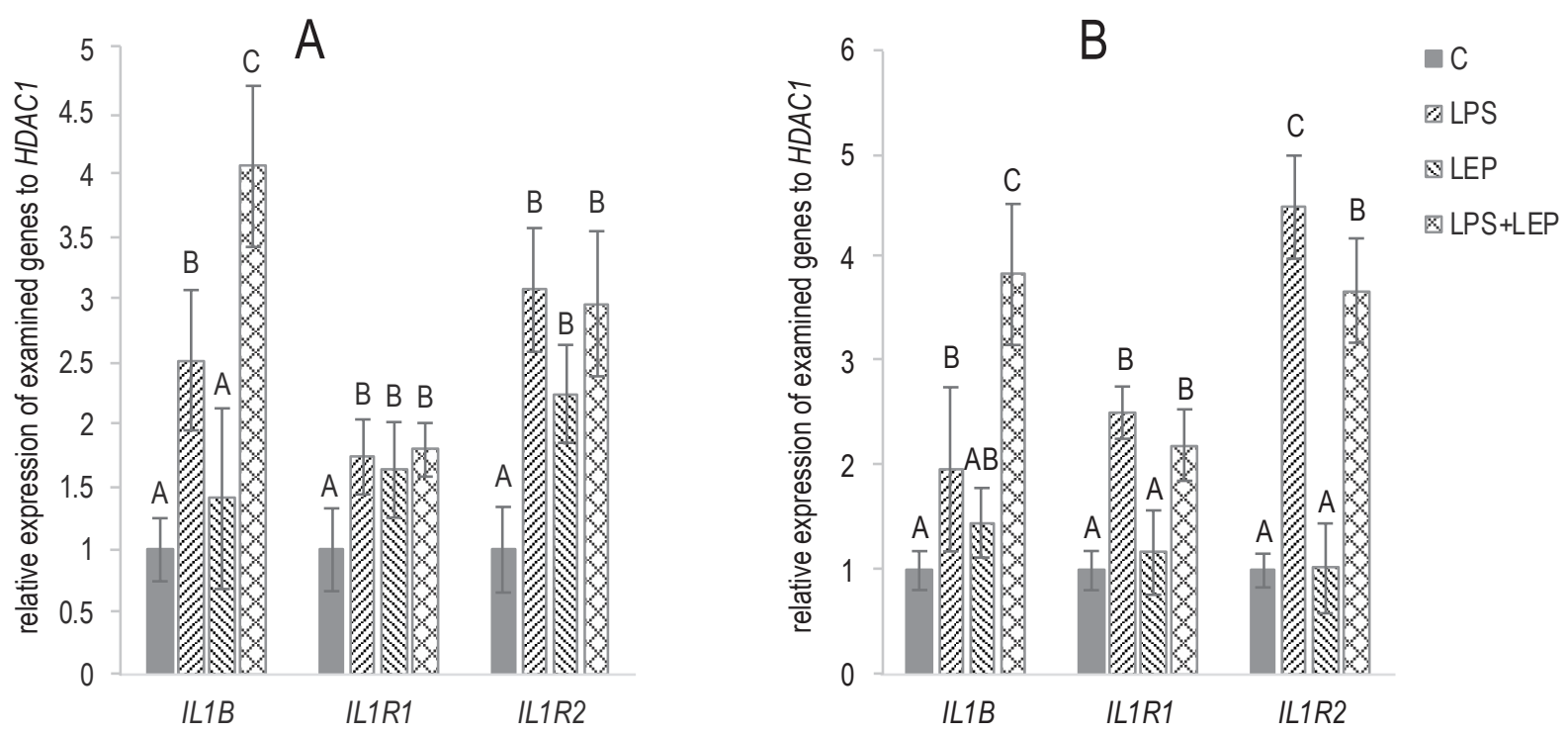

Figure 2. Relative gene expression of interleukin-1 $\beta(I L 1 B)$ and its receptor type 1 and 2 (IL1R1 and IL1R2, respectively) in ewe's aorta during short-day (A) and long-day (B) seasons

$A B C$ - bars with different superscripts are significantly different according to two-way ANOVA with post-hoc Tukey's test, for each gene separately, at $P \leq 0.05$

gene expression in both seasons regardless leptin injection (ANOVA, $P \leq 0.0001$ for all three genes in both seasons). The IL6 and IL6ST gene expression was enhanced and $I L 6 R$ was decreased after LPS injection. The single exogenous leptin injection increased IL6 gene expression but only in SD season (Tukey's test, C vs LEP, $P \leq 0.05$ ); however no cumulative effect of LPS and leptin action was stated in this season. On the other hand in the LD season leptin enhanced the LPS effect on IL6 gene expression (Tukey's test, LPS $v s$ LPS+LEP, $P \leq 0.001)$. Neither IL6R and IL6ST gene expressions were influenced by leptin administration regardless of the studied season.

\section{Tumour necrosis factor (TNF) $\alpha$ and its receptors (Figure 4)}

In SD season $3 \mathrm{~h}$ after singular LPS injection no effect on TNFA and TNFAR1 gene expression was 

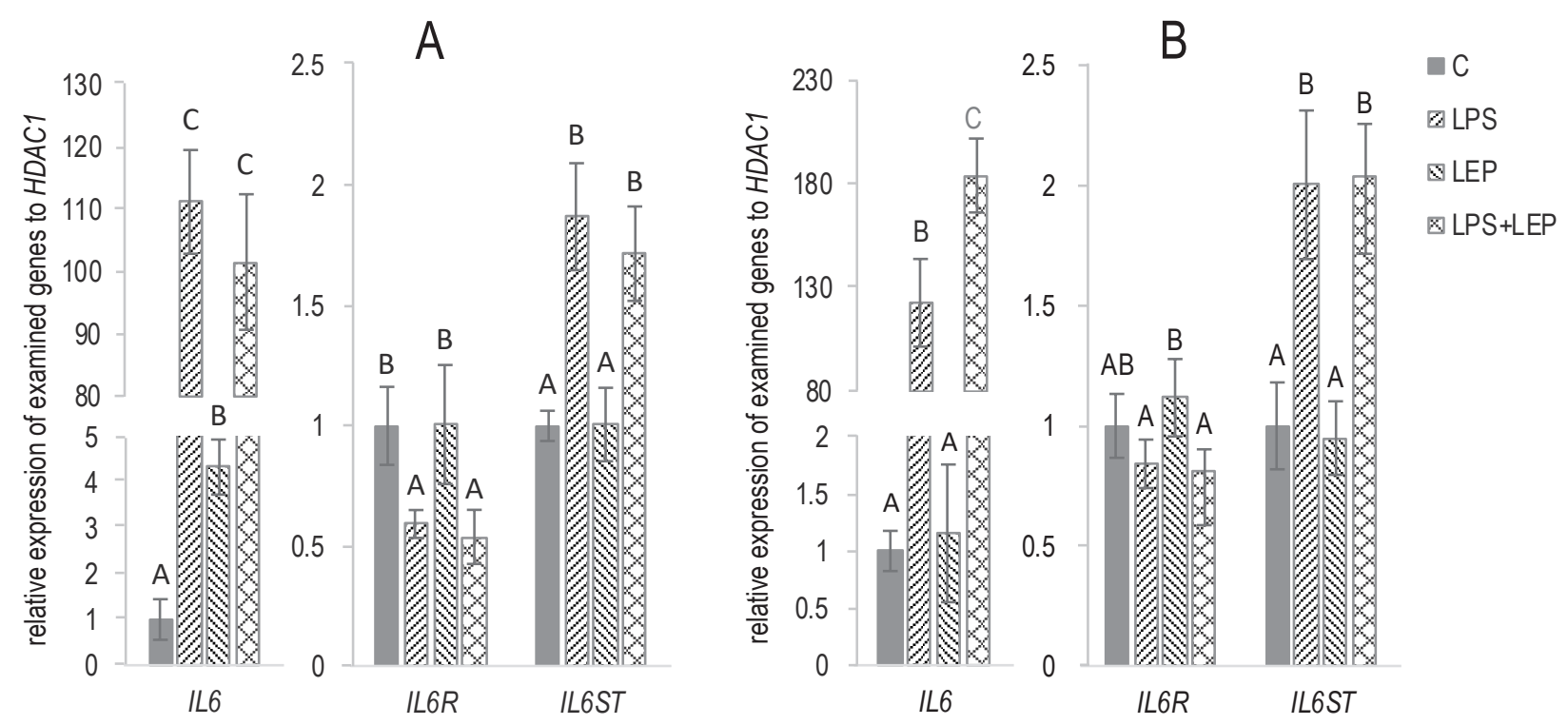

Figure 3. Relative gene expression of interleukin-6 (IL6), its receptor (IL6R) and signal transducer (IL6ST) in ewe's aorta during short-day (A) and long-day $(B)$ seasons

$\mathrm{ABC}$ - bars with different superscripts are significantly different according to two-way ANOVA with post-hoc Tukey's test, for each gene separately, at $P \leq 0.05$

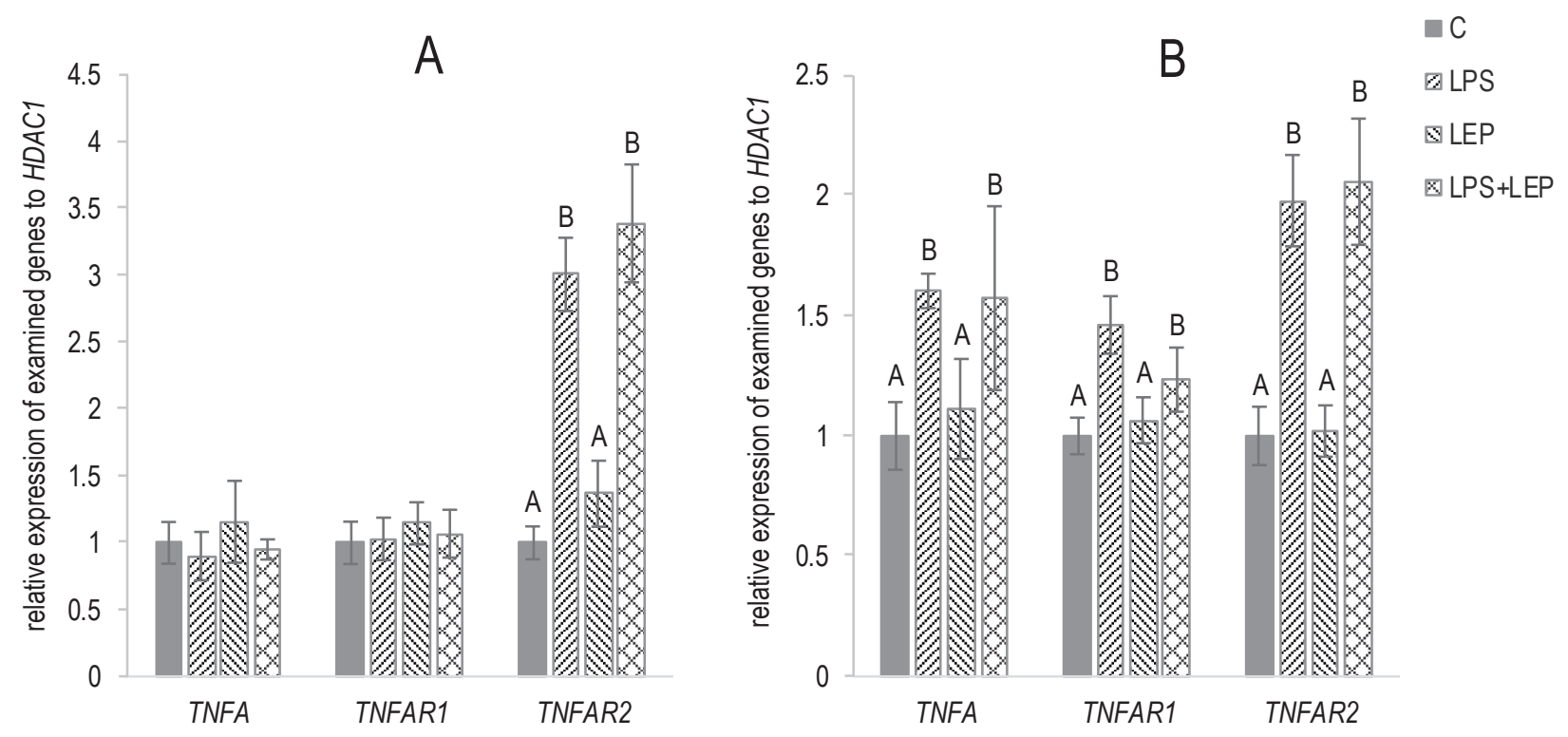

Figure 4. Relative gene expression of tumour necrosis factor a (TNFA) and its receptor type 1 and 2 (TNFAR1 and TNFAR2, respectively) in ewe's aorta during short-day (A) and long-day (B) seasons

$A B C$ - bars with different superscripts are significantly different according to two-way ANOVA with post-hoc Tukey's test, for each gene separately, at $P \leq 0.05$

stated; however the LPS increased TNFAR2 mRNA level (ANOVA, $P \leq 0.0001$ ). In the LD season the stimulating effect of endotoxin on all three examined genes was observed (ANOVA, $P \leq 0.0001$ for all three genes). Neither TNFA nor its receptors gene expression was influenced by leptin, regardless photoperiodic conditions.

\section{Discussion}

Inflammation plays a crucial role in the atherosclerosis formation. Knowing that leptin is strictly connected with inflammation progress in the vessels and that sheep is characterised by natural leptin resistance during LD (Szczesna and Zieba, 2015), 
it seems reasonable to carry out an experiment focused on photoperiodic conditions influence on exogenous leptin action on gene expression of proinflammatory cytokines and their receptors with or without prior acute stress induction.

The usage of LPS to trigger inflammation and so being a model in atherosclerosis is strictly connected with TLR4 activation. In intact arteries TLR4 can be only detected in the intimal dendric cells. However, in human arteries with atherosclerotic changes, an increased expressions of TLR4 on endothelial cells, macrophages, smooth muscle cells, fibroblasts and, to a lesser extent, on $\mathrm{T}$ lymphocytes are observed. Howell et al. (2011) stated that TLR4 is necessary for ox-LDL-induced macrophage differentiation to foam cells. Su et al. (2011) observed ox-LDL colocalization with TLR4 and stated that in human coronary arterial endothelial cells (CAECs) ox-LDL induces bone morphogenetic protein-2 (BMP-2) expression through TLR2 and TLR4, which plays an important role in atherosclerotic vascular calcification. Moreover, increased levels of TLR4 are expressed by macrophages in human lipid-rich atherosclerotic plaques (Katsargyris et al., 2010). On the other hand, lack of TLR4 suppresses atherosclerosis and alters plaque phenotype in mice deficient in apolipoprotein E (Michelsen et al., 2004). So, TLR4 seems to be crucial in atherosclerosis progression. In the present study LPS injection increased TLR4 expression, which is generally known. However the interaction between leptin and TLR4 is not fully examined and the studies focused on connection between TLR4 and leptin are based mostly on adipose tissue examination (Batra et at., 2007). In the present study the leptin effect on TLR4 gene expression was only stated in SD season, which confirms the photoperiod-dependent influence of leptin in ewe.

The TLR4 induction accelerate the synthesis of pro-atherogenic cytokines such as IL-1 $\beta$, IL-6, TNF $\alpha$, which were examined also in the present study. It was found that leptin administration potentates stimulatory effect of LPS on $I L 1 B$ gene expression in aorta, but the individual effect of leptin on $I L 1 B$ gene expression was not stated. IL- $1 \beta$ is considered as one of the most potent pro-inflammatory cytokines promoting vascular inflammation, as it promotes the expression of other cytokines (e.g., IL-6), adhesion molecules, and the migration and mitogenesis of vascular smooth muscle (Tousoulis et al., 2016). So, the inhibition of IL-1 $\beta$ activity has become a potential therapeutic target in the prevention and treatment of atherosclerosis. For example in Canakinumab Anti-Inflammatory Thrombosis
Outcome Study (CANTOS), a human monoclonal antibody, canakinumab, which acts selectively on IL-1 $\beta$ but not on IL-1 $\alpha$, was examined (Libby, 2017). Although there are no works presenting leptin effect on cytokines synthesis in sheep tissue, there are several studies conducted on rats, however not in the context of aorta. Luheshi et al. (1999) stated that leptin increased Il-1 $\beta$ in the hypothalamus of rats, furthermore leptin actions on appetite and body temperature were abolished by $\mathrm{IL}-1$ receptor antagonist (IL-1 ra) or in mice lacking IL-1 receptor. Sachot et al. (2004) showed that leptin is a circulating mediator of LPS-induced anorexia and fever probably through a hypothalamic IL- $1 \beta$-dependent mechanism (but not IL6-dependent one) as fever and anorexia were attenuated in the presence of leptin antiserum. Moreover Hosoi et al. (2002) confirmed their thesis that leptin regulates IL- $1 \beta$ expression in the brain via the STAT3-independent mechanisms conducting research on $\mathrm{db} / \mathrm{db}$ rodents, which do not possess active long form of leptin receptor. In the organism IL-1 $\beta$ effects are strictly connected with its receptor type I and II presence (IL-1R1 and IL$1 \mathrm{R} 2$, respectively). However in the present study we observed the effect of leptin on ILIRI and ILIR2 expressions only in SD season. It should be stressed that although IL- $1 \beta$ can be bound by two receptors, only IL1-R1 is able to transduce signal to the inside of the cell. IL-1R2 acts as a decoy receptor and so reduces the amount of IL-1 $\beta$ for the appropriate receptor - IL-1R1. The simultaneous effect of leptin on both receptors can show the active response of tissue to exogenous leptin injection, probably in the aim to keep the homeostasis of IL- $1 \beta$ activity. In LD season no effect of leptin on IL-1 $\beta$ receptors is stated, which can confirmed the decreased sensitivity of aorta on leptin action in this photoperiod. However, regardless examined season, leptin enhanced stimulatory effect of LPS on $I L 1 B$, which can stress the pro-inflammatory activity of leptin in aorta of ewes with induced acute inflammation. Moreover, in both seasons the increase in $I L 1 B$ expression in groups with LPS and leptin treatment is rather similar (4fold increase in LPS+LEP groups $v s$ control group), which can suggest that photoperiod is not an essential factor for leptin effects on IL-1 $\beta$ stimulation but it is crucial for IL-1 $\beta$ receptors gene expression.

One of the main IL-1 $\beta$ effects is to elaborate another cytokine, IL-6. IL-6 has pleiotropic influence on organism functioning. As it was observed by Harden et al. (2006), IL-6 with leptin participation is responsible for the induction of a sickness behaviour symptoms after LPS injection (increased 
temperature, lack of appetite). Also in the cardiovascular system disease IL-6 is an upstream inflammatory cytokine that plays a key role in propagating the downstream inflammatory response responsible for atherosclerosis. It also augments thrombosis and inhibits fibrinolysis participating in atherothrombosis (Hartman and Frishman, 2014). So, the pharmaceutical studies are conducted on the IL-6 inhibitor, tocilizumab, showing improvement in endothelial function and reduction in aortic stiffness and its usage in atherosclerosis treatment (Protogerou et al., 2011). In the present study the increase in IL6 gene expression after LPS injection was 110-fold whereas for $I L 1 B$ only 2 -fold. Interestingly, there was no seasonal difference in LPS effects on IL6, its receptor and signal transducer gene expression in sheep aorta which is in contrast to thoracic perivascular adipose tissue (PVAT) in which sensitivity to LPS was higher in SD season (data in press). However in the aorta exogenous leptin influence on IL6 expression in SD but not in the LD season was stated. This may also confirm increased sensitivity of the examined tissue to leptin in this season. In LD season effect of leptin was only stated as stimulator to LPS action, which suggests the need for prior inflammation trigger presence to see the effects of leptin on IL6.

Besides IL- $1 \beta$ and IL-6, the important role in atherosclerosis progression is played by TNF $\alpha$. In the vessels $\mathrm{TNF} \alpha$ reduces NO bioavailability, induces oxidative stress and reactive oxygen substrates (ROS) formation or increases pro-inflammatory cytokines synthesis, playing a significant role in the vascular function impairment (DeVallance et al., 2018). Also, the circulating levels of both TNF $\alpha$ receptors (TNFAR1 and TNFAR2) are increased in both obesity and in non-obesity adults with pro-atherogenic lipid profiles (Mohamed-Ali et al., 1999). However in the present study the intravenous injection of leptin did not exert effect on TNFA expression regardless the examined season and the presence of acute inflammation; also TNF $\alpha$ receptors genes expression was not affected by leptin. Such results may suggest that in ewe aorta leptin does not act via TNF $\alpha$, regardless photoperiodic conditions. The obtained results show the tissue-dependent effect of leptin on this cytokines as several studies confirm leptin effect on TNF $\alpha$. Basing on microarray profiling of human white adipose tissue (WAT), Taleb et al. (2006) concluded that leptin can act on this tissue, especially on the expression of genes related to inflammation and immunity including TNF $\alpha$. Lee et al. (2014) stated that leptin increases TNF $\alpha$ in Raw 264.7 cells acting by the pathway: phospholipase C (PLC $\gamma$ )/ Src/ phospholipase D1 (PLD1)/ phosphatidic acid (PA)/ p70S6K/ c-jun N-terminal protein kinase (JNK). They stated that leptin enhanced the activity of PLD1 through activation of PLC $\gamma$ and Src, while PLD1 siRNA decreased the leptin-induced expression and production of TNF $\alpha$. Leptin-induced PLD activation was also inhibited by a PLC $\gamma$ inhibitor (POA) and Src kinase inhibitor (PP2) indicating PLC $\gamma$ and Src kinase are upstream activators of PLD1. Earlier Shen et al. (2005) showed that leptin can enhance TNFa via JNK and p38 MAPK pathways in LPS-stimulated Kupffer cells. Also in the thoracic PVAT of ewes used also in the present experiment leptin stimulated the expression of TNFA, regardless the photoperiodic conditions, and TNFAR 1 and TNFAR 2 but only in SD season (data in press).

\section{Conclusions}

In thoracic aorta tissue a single injection of exogenous leptin exerts effect on gene expression of pro-inflammatory cytokines and their receptors; however in ewe this influence is dependent from photoperiodic conditions and is different for each cytokine. Moreover leptin can moderate progression of the inflammation reaction in this tissue intensifying endotoxin-induced expression of pro-inflammatory cytokines (IL-1 $\beta$ and IL-6). In conclusion, it was shown that sheep is an interesting large animal model that can be used in both immunological and cardiovascular studies, and can therefore be useful in human medicine research.

\section{Acknowledgments}

The research was supported by the Polish National Science Centre grant 'SONATA' no. 2013/11/D/NZ9/02536.

\section{References}

Azevedo L. (Editor), 2012. Sepsis - an Ongoing and Significant Challenge. InTech London(UK), https://doi.org/10.5772/2958

Batra A, Pietsch J., Fedke I., Glauben R., Okur B., Stroh T., Zeitz M., Siegmund B., 2007. Leptin-dependent toll-like receptor expression and responsiveness in preadipocytes and adipocytes. Am. J. Pathol. 170, 1931-1941, https://doi. org/10.2353/ajpath.2007.060699

Beltowski J., 2006. Leptin and atherosclerosis. Atherosclerosis 189, 47-60, https://doi.org/10.1016/j.atherosclerosis.2006.03.003

Beręsewicz A. (Editor), 2011. Pathophysiology of atherosclerosis and ischemic heart disease (in Polish: Patofizjologia miażdżycy i choroby niedokrwiennej serca). Centrum Medycznego Kształcenia Podyplomowego Wydawnictwo. Warsaw (Poland) 
Camacho P., Fan H., Liu Z et al., 2016. Large mammalian animal models of heart disease. J. Cardiovas. Develop. Dis. 3, 30, https://doi.org/10.3390/jcdd3040030

Chilliard Y., Delavaud C., Bonnet M., 2005. Leptin expression in ruminants: Nutritional and physiological regulations in relation with energy metabolism. Domestic Anim. Endocrinol. 29, 3-22, https://doi.org/10.1016/j.domaniend.2005.02.026

DeVallance E., Branyan K.W., Lemaster K., Olfert I.M., Smith D.M., Pistilli E.E., Frisbee J.C., Chantler P.D., 2018. Aortic dysfunction in metabolic syndrome mediated by perivascular adipose tissue TNFa- and NOX2-dependent pathway. Exp. Physiol. 103, 590-603, https://doi.org/10.1113/EP086818

Duchenne J., Claus P., Pagourelias E.D., Mada R.O., Van Puyvelde J., Vunckx K., Verbeken E., Gheysens O., Rega F., Voigt J.U., 2018. Sheep can be used as animal model of regional myocardial remodelling and controllable work. Cardiol. J. https://doi.org/10.5603/CJ.a2018.0007

Frantz S., Ertl G., Bauersachs J., 2007. Mechanism of disease: Tolllike receptors in cardiovascular disease. Nat. Clin. Pract. Cardiovasc. Med. 4, 444-454, https://doi.org/10.1038/ ncpcardio0938

Harden L.M., du Plessis I., Poole S., Laburn H.P., 2006. Interleukin-6 and leptin mediate lipopolysaccharide-induced fever and sickness behavior. Physiol. Behavior 89, 146-155, https:// doi.org/10.1016/j.physbeh.2006.05.016

Hartman J., Frishman W.H., 2014. Inflammation and atherosclerosis: a review of the role of interleukin- 6 in the development of atherosclerosis and the potential for targeted drug therapy. Cardiol. Rev. 22, 147-151, https://doi.org/10.1097/ CRD.0000000000000021

Herman A., Misztal T., Herman A., Tomaszewska-Zaremba D., 2010. Expression of interleukin (IL)-1 $1 \beta$ and IL-1 receptors genes in the hypothalamus of anoestrous ewes after lipopolysaccharide treatment. Reprod. Domest. Anim. 45, e426-e433, https:// doi.org/10.1111/j.1439-0531.2010.01595.x

Herman A.P., Krawczyńska A., Bochenek J., Antushevich H., Herman A., Tomaszewska-Zaremba D., 2014. Peripheral injection of SB203580 inhibits the inflammatorydependent synthesis of proinflammatory cytokines in the hypothalamus. BioMed Res. Int. 2014, 1-10, https://doi. org/10.1155/2014/475152

Herman A.P., Tomaszewska-Zaremba D., 2010. Effect of endotoxin on the expression of $\mathrm{GnRH}$ and $\mathrm{GnRHR}$ genes in the hypothalamus and anterior pituitary gland of anestrous ewes. Anim. Reprod. Sci. 120, 105-111, https://doi.org/10.1016/j. anireprosci.2010.03.011

Hosoi T., Okuma Y., Nomura Y., 2002. Leptin regulates interleukin1 beta expression in the brain via the STAT3-independent mechanisms. Brain Res. 949, 139-146, https://doi. org/10.1016/S0006-8993(02)02974-8

Howell K.W., Meng X., Fullerton D.A., Jin C., Reece T.B., Cleveland J.C. Jr., 2011. Toll-like receptor 4 mediates oxidized LDL-induced macrophage differentiation to foam cells. J. Surg. Res. 171, e27-e31, https://doi.org/10.1016/j.jss.2011.06.033

Katsargyris A., Theocharis S.E., Tsiodras S., Giaginis K., Bastounis E., Klonaris C., 2010. Enhanced TLR4 endothelial cell immunohistochemical expression in symptomatic carotid atherosclerotic plaques. Expert Opin. Ther. Targets 14, 1-10, https://doi.org/10.1517/14728220903401294

Krawczyńska A., Olczak E., Rembiszewska A., GromadzkaOstrowska J., 2013. High-fat, cholesterol-rich diet affects leptin expression in the aortic layers. Exp Biol Med 238, 47-56, https://doi.org/10.1258/ebm.2012.012228
Krawczyńska A., Olczak E., Rembiszewska A., Herman A.P., Gromadzka-Ostrowska J., $2014 . \quad$ Time-dependent supplementation of vitamin $\mathrm{E}$ influences leptin expression in the aortic layers of rats fed atherogenic diet. J. Physiol. Pharmacol. 65, 33-39

Król K., Tomaszewska-Zaremba D., Herman A., 2016. Photoperioddependent effect of inflammation on nocturnal gene expression of proinflammatory cytokines and their receptors in pars tuberalis of ewe. J. Anim. Feed Sci. 25, 3-11, https:// doi.org/10.22358/jafs/65581/2016

Kumar H., Kawai T., Akira S., 2011. Pathogen recognition by the innate immune system. Int. Rev. Immunol. 30, 16-34, https://doi.org/ 10.3109/08830185.2010.529976

Lee S.-M., Choi H.-J., Oh C.-H., Oh J.-W., Han J.-S., 2014. Leptin increases TNF-a expression and production through phospholipase D1 in Raw 264.7 cells. PLoS ONE 9, e102373, https://doi.org/10.1371/journal.pone. 0102373

Libby P., 2017. Interleukin-1 beta as a target for atherosclerosis therapy. J. Am. Coll. Cardiol. 70, 2278-2289, https://doi. org/10.1016/j.jacc.2017.09.028

Luheshi G.N., Gardner J.D., Rushforth D.A., LoudonA.S., Rothwell N.J., 1999. Leptin actions on food intake and body temperature are mediated by IL-1. Proc. Natl. Acad. Sci. U.S.A. 96, 70477052, https://doi.org/10.1073/pnas.96.12.7047

Maciel M.N., Zieba D.A., Amstalden M., Keisler D.H., Neves J.P., Williams G.L., 2004. Chronic administration of recombinant ovine leptin in growing beef heifers: effects on secretion of $\mathrm{LH}$, metabolic hormones, and timing of puberty. J. Anim. Sci. 82, 2930-2936, https://doi.org/10.2527/2004.82102930x

Michelsen K.S., Wong M.H., Shah P.K., Zhang W., Yano J., Doherty TM., Akira S., Rajavashisth T.B., Arditi M., 2004. Lack of Tolllike receptor 4 or myeloid differentiation factor 88 reduces atherosclerosis and alters plaque phenotype in mice deficient in apolipoprotein E. Proc. Natl. Acad. Sci. U. S. A. 101, 1067910684, https://doi.org/10.1073/pnas.0403249101

Milani-Nejad N., Janssen P.M.L., 2014. Small and large animal models in cardiac contraction research: advantages and disadvantages. Pharmacol. Therap. 141, 235-249, https:// doi.org/10.1016/j.pharmthera.2013.10.007

Mohamed-Ali V., Goodrick S., Bulmer K., Holly J.M.P., Yudkin J.S., Coppack S.W., 1999. Production of soluble tumor necrosis factor receptors by human subcutaneous adipose tissue in vivo. Am. J. Physiol. 277, E971-E975, https://doi.org/10.1152/ ajpendo.1999.277.6.E971

Protogerou A.D., Zampeli E., Fragiadaki K., Stamatelopoulos K., Papamichael C., Sfikakis P.P., 2011. A pilot study of endothelial dysfunction and aortic stiffness after interleukin-6 receptor inhibition in rheumatoid arthritis. Atherosclerosis 219, 734736, https://doi.org/10.1016/j.atherosclerosis.2011.09.015

Sachot C., Poole S., Luheshi G.N., 2004. Circulating leptin mediates lipopolysaccharide-induced anorexia and fever in rats: Leptin, a circulating mediator of inflammation. J. Physiol. 561, 263272, https://doi.org/10.1113/jphysiol.2004.074351

Scheiermann C., Kunisaki Y., Frenette P.S., 2013. Circadian control of the immune system. Nat. Rev. Immunol. 13, 190-198, https:// doi.org/10.1038/nri3386

Schroeter M.R., Schneiderman J., Schumann B., Glückermann R., Grimmas P., Buchwald A.B., Tirilomis T., Schöndube F.A., Konstantinides S.V., Schäfer K., 2007. Expression of the leptin receptor in different types of vascular lesions. Histochem. Cell Biol. 128, 323-333, https://doi.org/10.1007/ s00418-007-0319-1 
Shen J., Sakaida I., Uchida K., Terai S., Okita K., 2005. Leptin enhances TNF-a production via p38 and JNK MAPK in LPSstimulated Kupffer cells. Life Sci. 77, 1502-1515, https://doi. org/10.1016/j.lfs.2005.04.004

Sikka G., Yang R., Reid S., Benjo A., Koitabashi N., Camara A., Baraban E., O'Donnell C.P., Berkowitz D.E., Barouch L.A., 2010. Leptin is essential in maintaining normal vascular compliance independent of body weight. Int. J. Obesity 2010, 34, 203-206, https://doi.org/10.1038/ijo.2009.208

Strzetelski J.A., Brzóska F., Kowalski Z.M., Osięgłowski S., 2014. Feeding Recommendation for Ruminants and Feed Tables (in Polish: Zalecenia Żywieniowe dla Przeżuwaczy i Tabele wartości pokarmowej pasz). National Research Institute of Animal Production. Krakow (Poland)

Su X., Ao L., Shi Y., Johnson T.R., Fullerton D.A., Meng X., 2011. Oxidized low density lipoprotein induces bone morphogenetic protein-2 in coronary artery endothelial cells via Toll-like receptors 2 and 4. J. Biol. Chem. 286, 12213-12220, https:// doi.org/10.1074/jbc.M110.214619

Szczesna M., Zieba D.A., 2015. Phenomenon of leptin resistance in seasonal animals: the failure of leptin action in the brain. Domest. Anim. Endocrinol. 52, 60-70, https://doi. org/10.1016/j.domaniend.2015.03.002
Taleb S., Haaften R., Henegar C. et al., 2006. Microarray profiling of human white adipose tissue after exogenous leptin injection. Eur. J. Clin. Invest. 36, 153-163, https://doi.org/10.1111/ j.1365-2362.2006.01614.x

Tousoulis D., Oikonomou E., Economou E.K., Crea F., Kaski J.C., 2016. Inflammatory cytokines in atherosclerosis: current therapeutic approaches. Eur. Heart J. 37, 1723-1732, https:// doi.org/10.1093/eurheartj/ehv759

World Health Organization (WHO), 2011. Global status report on noncommunicable disaeses 2010. Geneva (Switzerland)

Yen T.T., Allan J.A., Pearson D.V., Schinitsky M.R., 1977. Dissociation of obesity, hypercholesterolemia and diabetes from atherosclerosis in ob/ob mice. Experientia 33, 995-996, https://doi.org/10.1007/BF01945927

Yin K., Tang S.L., Yu X.H. et al., 2013. Apolipoprotein A-I inhibits LPS-induced atherosclerosis in ApoE(-/-) mice possibly via activated STAT3-mediated upregulation of tristetraprolin. Acta Pharmacol. Sin. 34, 837-846, https://doi.org/10.1038/ aps.2013.10

Zieba D.A., Szczesna M., Klocek-Gorka B., Williams G.L., 2008. Leptin as a nutritional signal regulating appetite and reproductive processes in seasonally-breeding ruminants. J. Physiol. Pharmacol. 59, Suppl. 9, 7-18 